\title{
MODERN MODEL FORMATION OF DRUG PROVISION OF PATIENTS WITH COMMUNITY-ACQUIRED PNEUMONIA IN KABARDINO-BALKARIA
}

\author{
Adisa A. Umirova ${ }^{1}$, Vsevolod L. Adzhienko ${ }^{1}$, Taisiya I. Kabakova ${ }^{1}$, \\ Eleonora A. Korzhavykh², Vladimir V. Gatsan ${ }^{1}$ \\ ${ }^{1}$ Pyatigorsk Medical and Pharmaceutical Institute - branch of Volgograd State Medical University, \\ 11, Kalinin ave., Pyatigorsk, Russia 357532 \\ ${ }^{2}$ Russian Peoples' Friendship University, Block 2, 10, Miklukho-Maklay St., Moscow, Russia 117198
}

E-mail: kabtais@mail.ru

The increase in the incidence of community-acquired pneumonia (CAP) is a major problem of national and regional importance. Its pharmacotherapy is based on the active use of antibacterial drugs. That requires a special attention of both, a doctor and a patient, the search for all new and advanced medicines (drugs).

The aim of the study is to justify and develop a regional model of drug provision of pharmacotherapy in community-acquired pneumonia.

Materials and methods. The use of the resource approach and the methodology of pharmaceutical care (PhC) for the formation of a modern model of drug supply have been tested. Logical, retrospective, sociological, pharmacoeconomic, marketing, statistical and other analytical methods have been used. The materials were official statistics, literature data and the results of the research carried out by the authors themselves.

Results. The state and tendencies of development of organizational, personnel, financial (population) and drug resources as the external factors affecting PhC to patients with CAP in the Kabardino-Balkarian Republic (KBR) have been identified. The following internal factors of PhC have been defined: medical prescriptions, consumer demands and the cost of pharmacotherapy. A model of drug provision for patients with CAP in the region has been formed. It is aimed at increasing the effectiveness of treatment, taking into account the stage of treatment and the price factor.

Conclusion. Under the conditions of a particular region, the use of the resource approach and the PhC methodology allows to more accurately identify the problems and risks of both drug provision and pharmacotherapy of the patients' population under study, and form a model adequate to reality, develop recommendations for all participants of $\mathrm{PhC}-\mathrm{a}$ doctor, a patient and a pharmaceutist (a pharmacist).

Keywords: community-acquired pneumonia (CAP), patients, drug provision, model, pharmaceutical care (PhC), resource approach, Kabardino-Balkaria

For citation: A.A. Umirova, V.L. Adzhienko, T.I. Kabakova, E.A. Korzhavykh, V.V. Gatsan. Modern model formation of drug provision of patients with community-acquired pneumonia in Kabardino-Balkaria. Pharmacy \& Pharmacology. 2019;7(3): 158-169. DOI: 10.19163/2307-9266-2019-7-3-158-169

(C) А.А. Умирова, В.Л. Аджиенко, Т.И. Кабакова, Э.А. Коржавых, В.В. Гацан, 2019

Для цитирования: А.А. Умирова, В.Л. Аджиенко, Т.И. Кабакова, Э.А. Коржавых, В.В. Гацан. Формирование современной модели лекарственного обеспечения пациентов с внебольничной пневмонией в Кабардино-Балкарии. Фармация и фармакология. 2019;7(3): 158-169. DOI: 10.19163/2307-9266-2019-7-3-158-169 


\title{
ФОРМИРОВАНИЕ СОВРЕМЕННОЙ МОДЕЛИ ЛЕКАРСТВЕННОГО ОБЕСПЕЧЕНИЯ ПАЦИЕНТОВ С ВНЕБОЛЬНИЧНОЙ ПНЕВМОНИЕЙ В КАБАРДИНО-БАЛКАРИИ
}

\author{
А.А. Умирова ${ }^{1}$, В.Л. Аджиенко, Т.И. Кабакова ${ }^{1}$, Э.А. Коржавых², В.В. Гацан ${ }^{1}$ \\ ${ }^{1}$ Пятигорский медико-фармацевтический институт - филиал федерального государственного \\ образовательного учреждения «Волгоградский государственный медицинский университет» \\ Министерства здравоохранения Российской Федерации, Россия \\ 357532, Ставропольский край, г. Пятигорск, пр. Калинина, 11 \\ ${ }^{2}$ Российский университет дружбы народов \\ 117198, г. Москва, ул. Миклухо-Маклая, д. 10, стр. 2
}

E-mail: kabtais@mail.ru

Получено 06.05.2019 Рецензия 1 29.05.2019 Рецензия 2 15.06.2019 Принята к печати 27.06.2019

Рост заболеваемости внебольничной пневмонией (ВП) является крупной проблемой государственного и регионального значения. Ее фармакотерапия базируется на активном применении антибактериальных препаратов, что требует особого внимания врача и пациента, поиска всё новых и совершенных лекарственных средств (ЛС).

Цель исследования - обоснование и разработка региональной модели лекарственного обеспечения фармакотерапии при ВП.

Материалы и методы. Проверялась применимость ресурсного подхода и методологии фармацевтической помощи (ФП) для формирования современной модели лекарственного обеспечения. Использованы логический, ретроспективный, социологические, фармакоэкономические, маркетинговые, статистические и другие аналитические методы. Материалами служили данные официальной статистики, литературные сведения и результаты собственных исследований.

Результаты. Выявлено состояние и тенденции развития организационного, кадрового, финансового (население) и лекарственного ресурсов как внешних факторов, влияющих на ФП пациентам с ВП в Кабардино-Балкарской Республике (КБР). Определены внутренние факторы ФП - назначения врачей, потребительский спрос и стоимость фармакотерапии. Сформирована модель лекарственного обеспечения пациентов с ВП в регионе, направленная на повышение эффективности лечения с учетом этапа лечения и ценового фактора.

Заключение. В условиях конкретного региона применение ресурсного подхода и методологии ФП позволяет более точно определить проблемы и риски как лекарственного обеспечения, так и фармакотерапии исследуемой популяции пациентов и сформировать адекватную реальности модель, выработать рекомендации для всех участников ФП - врача, пациента и провизора (фармацевта).

Ключевые слова: внебольничная пневмония, пациенты, лекарственное обеспечение, модель, фармацевтическая помощь, ресурсный подход, Кабардино-Балкария

\section{INTRODUCTION}

For many years, pneumonia has remained one of the most significant diseases for the population and health systems around the world. High mortality and disability rates, a particular vulnerability of children and elderly and old people, high financial costs of patients' treatment and elimination of severe consequences of the disease that have occurred - all these factors require close attention to finding the best strategy for pneumonia pharmacotherapy [1, 2].

In Russia, pneumonia is also a serious public health problem. According to the data of Russian Federal State Statistics Service, in the Russian Federation in the period from 2006 to the present, the incidence for every 100 thousand people of the adult population varies from 344.0 to 404.0 .

In these circumstances, according to a number of authoritative scientists [3-7], the real incidence may be significantly higher. Currently, CAP is the most common type of infection. The highest morbidity rates are recorded among the elderly people and children aged $4-5$ years $[2,8-11]$.

The result of the wrong treatment regime, late diagnosis of patients, incomplete elimination of the inflammatory process at discharge from hospital in patients with pneumonia is the transition from an acute form to chronic. In addition, uncontrolled therapy causes the emergence of antibiotic resistance. 30\% of pneumococcal strains today are known to have resistance to penicillin; the number of strains insensitive to cephalosporin antibiotics is growing progressively [12].

Such medical factors as diagnostic errors (approximately in $20 \%$ of cases), delays with diagnosis (on average for 3 days) and others, lead to the appearance of pharmacotherapy problems. With uncontrolled therapy, 
antibiotic resistance occurs more often. The economic damage from the elimination of these problems annually reaches 15 billion rubles. [13-15].

The experience of the developed countries of the world shows that in medical and pharmaceutical practice, overcoming the potential problems of pharmacotherapy is greatly facilitated by the application of the principles and techniques of specialized pharmaceutical care (PhC), focused primarily on optimizing medical and informational support of a doctor and a patient [16-22].

Over the past 20 years, PhCstudies in patients with various diseases have been carried out by Dremova N.B., Ovod A.I., Korzhavikh E.A. [23-26], Spichak I.V., Glembotsky G.T., Zakharova O.V., Alexeev I.V., Varenykh G.V., Trubina L.V., Petrov A.G. and others [27-33].

In pharmacy, only a few works are devoted to the improvement of drug supply for patients with pneumonia: by Z. Zakaryaeva [34], Wolfram N.A. [35].

No research has been carried out on the subject matter of $\mathrm{PhC}$ in relation to the situation in the Kabardino-Balkarian Republic. At the same time, as the study of profile literature shows, a regional approach to improving drug provision for patients with various nosological forms of diseases is increasingly used in modern pharmaceutical research, both in foreign [36-39] and in domestic kinds of research [40-42].

It is noted that in the conditions of modern Russia, due to its large extension, climatic-geographical, economic, socio-demographic differences between the constituent territories of the Russian Federation, the regional approach makes it possible to justify the problem and arrive at the most correct decisions in the sphere of drug provision.

The researchers emphasize the fact that the relevance of finding rational schemes for the treatment of pneumonia is due to the significant costs associated with not only drugs but also medical consumables. In addition, foreign scientists also include the cost of consulting a specialist, laboratory and diagnostic studies in the cost of treatment $[1,8,21,22,35,39]$.

All of theabove-listed indicates the relevance of a comprehensive analysis of drug supply issues for the subsequent rationalization of costs, as well as the achievement of the highest efficiency of drug treatment.

THE AIM of the study is to justify and develop a regional model of pharmacotherapy drug provision for patients with CAP.

\section{MATERIALS AND METHODS}

The objects of the study were statistical data on the Russian Federation and the KBR for 2008-2018, statistical reports of health care organizations, lists of drugs (State Register of Medicinal Remedies, vital essential and necessary medicines, treatment standards, etc.); the results of sociological surveys of doctors ( 30 questionnaires; a set sample), pharmacy workers (41 questionnaires), patients with CAP (70 questionnaires); price lists of wholesale and retail pharmaceutical organizations within the territory of the KBR (the actual range of drugs).

The leading research methods were: systematic, resource and regional approaches; methods of historical, logical, scientometric (content analysis), marketing (assortment structure, price), pharmacoeconomic (cost of disease) and economic and statistical analysis (grouping, variation statistics), sociological (questionnaire survey, expert assessments). The results were processed using standard computer programs.

On the basis of the preliminary research, a working hypothesis of the study was formulated: considering the problem from the standpoint of the resource approach and the ideology of specialized pharmaceutical care will allow the most complete and reasonable improvement of drug supply to patients with CAP within the territory of the KBR.

In accordance with this hypothesis, the following tasks were to be solved:

1. to assess the status and development trends of regional resources - organizational, personnel, financial (population), and drugs - as external factors of PhC for patients with CAP;

2. to characterize the internal factors of CAP pharmacotherapy in the KBR - doctors' prescriptions (stationary stage of medical care), consumer demand (outpatient stage), the cost of pharmacotherapy (inpatient and outpatient stages);

3. to form a regional conceptual model of drug provision for patients with CAP.

To ensure the theoretical unity of the study, the following terms and definitions were used:

- drug provision - an organizational system (a set of measures) to bring drugs from the manufacturer to the consumer (Shukil LV, 2018) ;

- drug care - a type of professional health care, aimed at the provision, prescription and use of drugs (Fomina AV, 2006) [43];

- pharmaceutical care - the system of drug, information and organizational-methodological support of individualized pharmacotherapy of specific diseases (Dremova N. B. et al., 2005) [26]. 
RESULTS AND DISCUSSION

At the first stage of the work, it was found out that in terms of socio-economic indicators, the KBR usually occupies middle positions of the seven subjects of the
North Caucasus Federal District (NCFD; Table 1). This confirms the validity of the choice of the KBR as a model region in our study.

Table 1 - Some socio-economic indicators of Kabardino-Balkaria

(according to Federal State Statistics Service data, $2018[3,4]$ )

\begin{tabular}{lc}
\hline \multicolumn{1}{c}{ Indicators } & KBR \\
\hline Area, thousandsquarekm & 12,5 \\
\hline Populationon 01.01.18, thousandpeople & 865,8 \\
\hline Average annual number of employed, thousand people & 362,6 \\
\hline Average per capita cash income (per month), rub. & 20385,0 \\
\hline Gross regional product in 2016, mln. rub. & 132706,9 \\
\hline
\end{tabular}

The following indicators of socio-demographic resource, compared with the average for the Russian Federation, refer to the features of the KBR region:

- lower proportion of the average annual number of the employed in the total population of the KBR;

- $\quad$ higher rate of population ageing;

- lower standard of living (subsistence minimum and per capita income);

- outstripping growth of the General morbidity.

In addition, the increase in the incidence of CAP per 100 thousand population for the period of 2013-2017 has been identified: 1) in the RF - by 1.06 times (in 2018 - already by 1.3 times), 2) in accordance with the resource approach, the pharmaceutical, organizational, human and medicinal resources of the model region have been evaluated, as they are most dependent on the state of the drug supply system.

Due to the lack of official statistics of pharmaceutical organizations to assess the pharmaceutical organizational resource in the country, we have analyzed the composition and structure of the collection of licensing entities (licensees) doing pharmaceutical activities in the region

It has been established that in 2018, there were 382 holders of 547 licenses for pharmaceutical activities in the KBR. By legal status, the majority of licensees -211 (55.2\%) - were legal entities; the number of individuals was 171 (44.8\%). The distribution of licensees according to the form of ownership is presented in Table 2.

Table 2 - Distribution of licensees for pharmaceutical activities in the Kabardino-Balkarian Republic according to the form of ownership (the data by the end of 2018)

\begin{tabular}{|c|c|c|c|}
\hline \multirow{2}{*}{ Formofownership } & \multirow{2}{*}{ Type of owner } & \multicolumn{2}{|c|}{ Quntity oflicensees } \\
\hline & & Absolute & Relative, \% \\
\hline Publicownership, including: & & 49 & 12.83 \\
\hline - state & $\begin{array}{l}\text { State autonomousInstitution (SAI), } \\
\text { State Budgetary Institution } \\
\text { (StateBudgetaryHealthcarelnstitution) } \\
\text { State Public Healthcare Institution (SPHI) }\end{array}$ & 37 & 9.69 \\
\hline - federal & $\begin{array}{l}\text { Federal Public Institution, Federal PublicHealthcare } \\
\text { Institution }\end{array}$ & 7 & 1.83 \\
\hline - municipal & $\begin{array}{l}\text { Municipal Unitary Enterprise (MUE), Municipal Unitary } \\
\text { Pharmaceutic Enterprise (MUPhE) }\end{array}$ & 5 & 1.31 \\
\hline Private, including: & & 333 & 87.17 \\
\hline - individual & self-employedentrepreneur (SEE) & 171 & 44.76 \\
\hline - collective & $\begin{array}{l}\text { Closed Joint-Stock Company (CJSC), } \\
\text { Open Joint-Stock Corporation (OJSC) }\end{array}$ & 162 & 42.41 \\
\hline
\end{tabular}

The results, shown in Table 2, indicate a clear predominance of private owners among pharmaceutical license holders $-87.17 \%$; these are mainly self-employed entrepreneurs, who account for almost half of all licensees and $40.77 \%$ of all licenses for pharmaceutical activities. 
The second important result is that medical, rather than pharmaceutical, organizations clearly dominate among publicly owned licensees. The latter include the autonomous public health care institution "Pharmacy Warehouse" of the Ministry of Health of the KBR and five pharmacy enterprises with municipal property; in total, they make up only $1.57 \%$ of all licensees, possessing seven licenses (1.28\%).

The third parameter that deserves attention is the ratio of urban and rural licensees. In our study, the corresponding number was $3.66: 1$, i.e. 300 licensees operating in urban areas (78.5\%) with $436(79.7 \%)$ licenses accounted for 82 (21.5\%) rural licensees with 111 (20.3\%) licenses.

Thus, an excessive concentration of a pharmaceutical organizational resource, including individual entrepreneurs, most often owners of pharmacies, in cities (79.7\% of licensees), is a problem, while almost half of the population of the republic lives in rural areas. This problem significantly reduces the availability of drug care to the rural population of the KBR.
In the process of evaluation of personnel pharmaceutical resource, it was found out that the statistical records of pharmaceutical personnel (pharmaceutists and pharmacists) at the Federal level are conducted only in respect of their training - the number of applicants and the number of graduates. Information on the number of pharmaceutists and pharmacists employed in the drug supply system at the country or regional level could not be identified from available sources.

In this regard, the estimated number of pharmaceutical professionals in Russia as a whole was determined using two different methods: 1 ) on the basis of extrapolation of official data, as of 1998, and 2) taking into account trends in the development of the pharmacy network of the country and the number of available pharmaceutists and pharmacists (Fig. 1 and 2 are based on the data of Federal State Statistics Service).

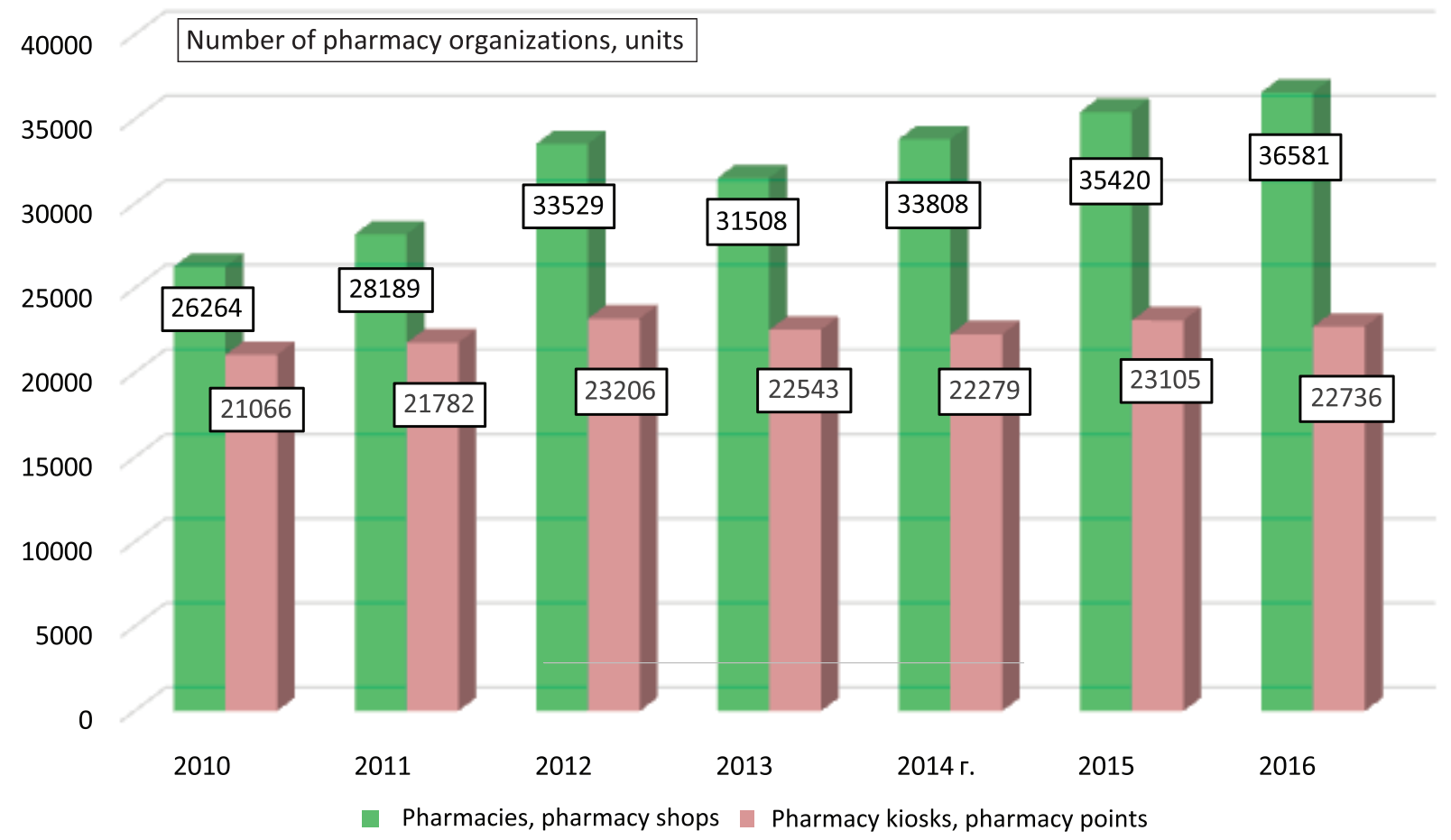

Figure 1 - Dynamics of the number of pharmacy organizations in Russia (2010-2016)

As a result, an estimated number of pharmaceutical workers has been determined: as of 2016, there can be at least 184.46 specialists with higher and secondary pharmaceutical education in the Russian Federation. Considering the personnel trained before 1995 and who have not yet reached the retirement age, as well as pensioners who continue to work in pharmacy organizations, this number can be increased to 200 thousand people or more.
The foregoing leads to the conclusion about the intensive development of the pharmaceutical human resources in the Russian Federation and the high availability of pharmaceutical personnel to the country's population. At the same time, the lack of official statistical records of pharmaceutical personnel, primarily in the regions, does not allow assessing the analyzed resource properly from the point of view of the actual state, the region's need for such personnel and the satisfaction of this need. 


\section{Number of graduates, thousand people}

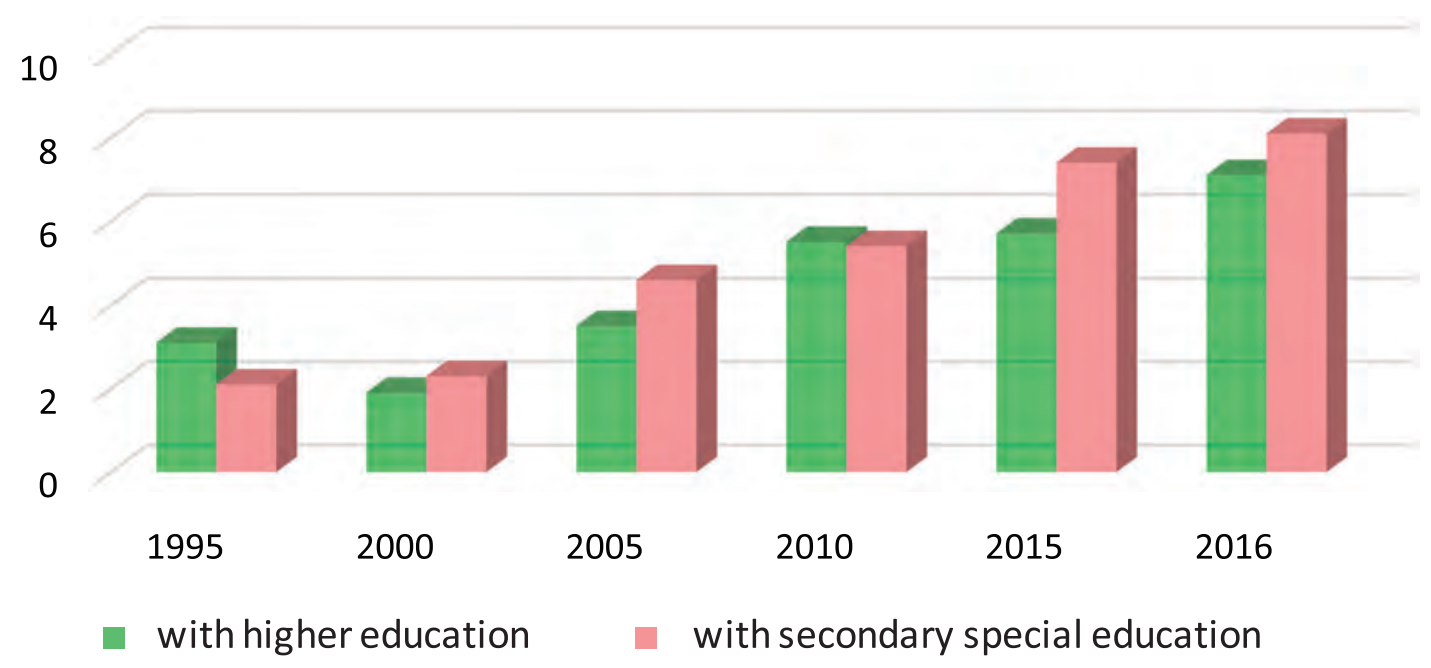

Figure 2 - Dynamics of the number of graduates in the specialty "Pharmacy" in Russia (1995-2016)

The methodical approach used further for the assessment of regional medicinal resource for CAP treatment, provided marketing characteristics of the resource in the qualitative and quantitative (assortment) and price aspects at the following levels:

- lists of drugs for CAP pharmacotherapy, which are the starting point for the assessment of the Russian market for this target segment and, accordingly,

- the wholesale pharmaceutical market of the $\mathrm{KBR}$;

- $\quad$ the retail pharmaceutical market of the KBR.

The sources of baseline information are the following: standards for providing medical care to patients with pneumonia in 2007 (severe forms with complications) and in 2012 (forms of moderate severity); State Register of Medicinal Products; Directory of Synonyms of Medicinal Products (Pharmaceutical Center, 2015); lists of vital and essential drugs, the minimum range of drugs needed for medical care, KBR Territorial programmeon State Guarantees, as well as price lists of distributors and pharmacy organizations.

Federal standards for pneumonia treatment have been established to include drugs under 18 international nonproprietary names (INN). The comparative analysis of the lists revealed the following facts:

- 14 INNs (78\%) are included in all 4 lists; 1 INN - Cefotaxime - is not included in the list of KBR Territorial programmeon State Guarantees, 3
INNs - a combination of amoxicillin+sulbactam, ketoconazole and netilmicin - are not included in the VED and Provision of Necessary Medicinal Products; five INNs (22\%) are included in the Minimum assortment list for pharmacy organizations;

- $\quad 72 \%$ of each INN is included in the regulative lists of vital essential and necessary medicines and Provision of Necessary Medicinal Products, on the basis of which preferential and free supply of medicines is carried out;

- 411 medicines in 42 dosage forms (non-recurring names) were registered under 322 trade names as 18 INNs mentioned in the standard of 2007;

- the total number of dosage forms was 392 for 411 drugs. At the same time, the widest range of dosage forms was noted for such drugs as Ciprofloxacin (44), Ambroxol and Azithromycin (41 each), the smallest - for the combination of Ipratropium bromide + Fenoterol and Netilmicin (3); the total number of the countries producing drugs of this target segment was 39 non-recurring names;

- the largest number of dosage forms accounted for tablets was 148 (37.76\%);

- the number of oral drugs (61.74\%) was twice as large as the number of parenteral ones (Table 3). 
Table 3 - Range of drugs used in pneumonia, according to the standard of 2007 (adopted as the base)

\begin{tabular}{|c|c|c|c|}
\hline $\begin{array}{l}\text { International Nonproprietary Name } \\
\text { (INN) }\end{array}$ & $\begin{array}{c}\text { Number of trade } \\
\text { names (TN) }\end{array}$ & $\begin{array}{l}\text { Number of dosage forms } \\
\text { (DF) }\end{array}$ & $\begin{array}{c}\text { Number of producing } \\
\text { countries }\end{array}$ \\
\hline \multicolumn{4}{|c|}{ Drugs affecting respiratory system } \\
\hline \multicolumn{4}{|c|}{ Other drugs for the treatment of respiratory organs diseases, not designated in other headings } \\
\hline Acetylcysteine & 12 & 17 & 6 countries \\
\hline \multicolumn{4}{|c|}{ Anti-asthmatics } \\
\hline Ipratropium bromide + Fenoterol & 3 & 3 & 3 countries \\
\hline Aminophylline & 6 & 6 & 3 countries \\
\hline Ambroxol & 33 & 41 & 18 countries \\
\hline \multicolumn{4}{|c|}{ Agents for prevention and treatment of infections } \\
\hline \multicolumn{4}{|c|}{ Antibacterial agents } \\
\hline Ampicillin & 5 & 7 & 3 countries \\
\hline Amoxicillin & 12 & 14 & 7 countries \\
\hline Amoxicillin + clavulanic acid & 23 & 28 & 11 countries \\
\hline Amoxicillin + sulbactam & 2 & 3 & 1 country \\
\hline Azithromycin & 29 & 41 & 9 countries \\
\hline Clarithromycin & 29 & 31 & 14 countries \\
\hline Moxifloxacin & 12 & 14 & 4 countries \\
\hline Netilmicin & 3 & 3 & 2 countries \\
\hline Cefuroxime & 17 & 21 & 10 countries \\
\hline Levofloxacin & 34 & 41 & 14 countries \\
\hline Cefotaxime & 23 & 21 & 9 countries \\
\hline Ciprofloxacin & 34 & 44 & 8 countries \\
\hline \multicolumn{4}{|c|}{ Antifungal agents } \\
\hline Fluconazole & 30 & 37 & 13 countries \\
\hline Ketoconazole & 15 & 20 & 8 countries \\
\hline Total: 18 INNs & 322 TNs (100\%) & $\begin{array}{c}392(100 \%) ; \\
42 \text { non-recurring names } \\
\text { of forms }\end{array}$ & $\begin{array}{l}39 \text { non-recurring } \\
\text { names of countries; } \\
411 \text { medicinal } \\
\text { preparations (100\%) }\end{array}$ \\
\hline
\end{tabular}

The obtained data were used for comparison with the actual state of the medicinal resource in the KBR, primarily in pharmaceutical wholesale organizations that meet the needs of hospital and retail sectors of the regional market in the target segment medicinal preparations for pneumonia treatment.

The assortment profiles made up for the target drug segment in the federal and regional (wholesale) markets, are presented in Fig. 3.

As Fig. 3 shows, the regional range is significantly poorer than that in the Russian Federation on the whole - in the number of INNs, the number of trade names and the number of dosage forms. However, in the KBR the proportion of oral drugs and tablets is significantly higher.

The revealed facts make it possible to draw a conclusion about the lack of completeness and breadth of the range of this target segment in the regional pharmaceutical market.
Thus, marketing studies have shown that the development of the regional medicinal resource for the CAP treatment is characterized by satisfying the need for the rangerecommended by the CAP treatment standards, by about $78 \%$, while oral drugs make up about $91 \%$. In the region, there is also a significant differentiation in drugs prices for the CAP treatment.

At the next stage, the internal factors of PhC affecting pharmacotherapy and its consequences for CAP patients were studied. The following factors have been established:

- pharmaceutists and pharmacists of pharmacy organizations are practically not considered by medical specialists as informants and consultants on drug issues. Consequently, the interaction in the process of pharmacotherapy as a mandatory element of $\mathrm{PhC}$ is not developed, and a high qualification of pharmaceutical workers is not used by doctors to the proper extent; 


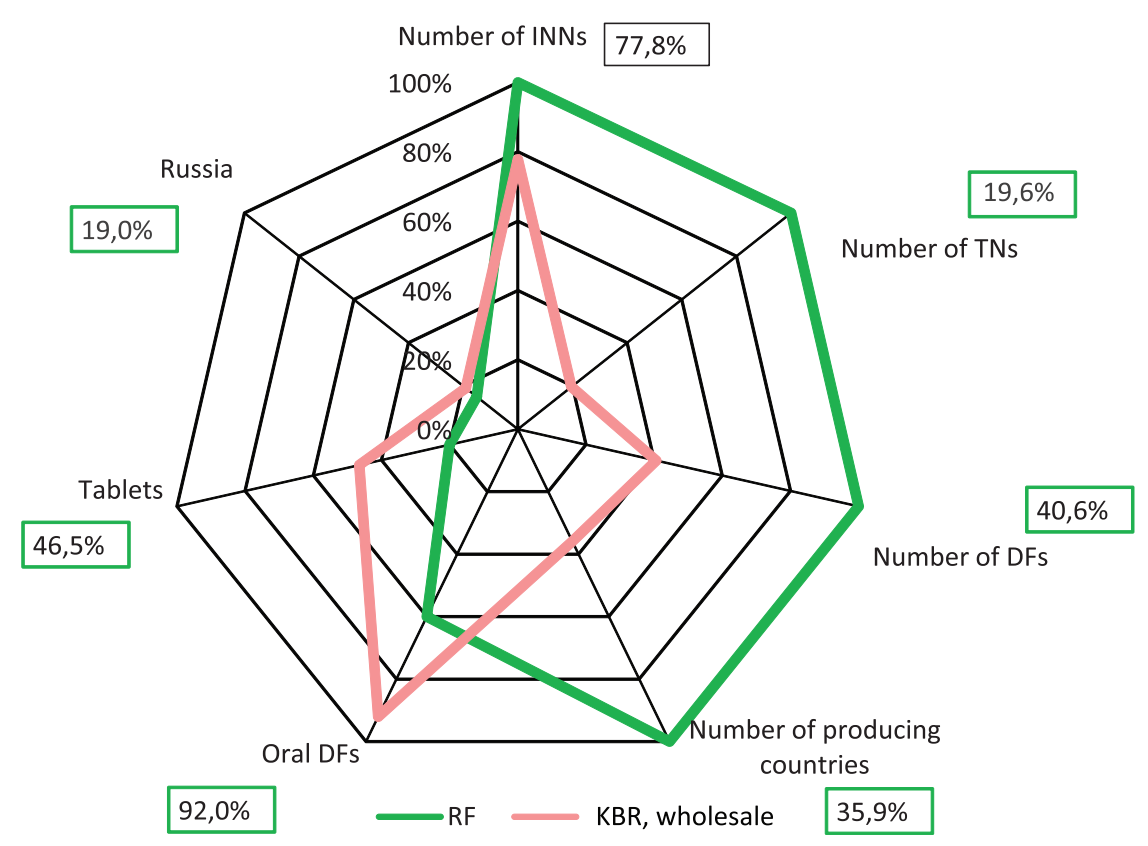

Figure 3 -Assortment profile of funds for pneumonia treatment

- the group of the highest medical trust (preferences) includes only one drug - Moxifloxacin; above the average confidence there is a combination of Ipratropium bromide + Fenoterol, Fluconazole, Acetylcysteine;

- according to the survey of pharmacists, the key factors determining a patient's choice when buying a drug for flu and cold treatment, are the price and recommendations of a pharmacists and a pharmaceutists $(60 \%$ and $43 \%$, respectively);

- only a quarter of patients $(23 \%)$ respond the doctor's recommendations. The data obtained are consistent with the results of an expert survey of doctors: all experts agree that self-treatment exacerbates the course of the disease;

- the highest consumer demand is typical of a group of remedies for symptom control (87\%);

- patients tend to change the prescribed therapy or make up an independent decision when choosing a drug therapy.

The revealed differences between pharmacy consumer demand and the preferred prescriptions of medical experts in relation to the required drugs indicates high risks in the self-selection of antibacterial drugs by patients; the consequences of these risks may be the inefficiency of the chosen pharmacotherapy, complications and side effects, increased resistance of microorganisms.

In the study of CAP in-patients, such negative behavioral characteristics of CAP patients as a high tendency to self-treatment and the use of antibiotics without a doctor's prescription were revealed. As a rule, the duration of the use of antibacterial drug is often not familiar to the patient.

These circumstances are consistent with the data obtained in the survey of medical experts and specialists of pharmacy organizations, and serve as an undoubted basis for purposeful informing patients about the properties and risks of the use of antibacterial agents without medical supervision.

Among the most influential factors of pharmacotherapy is the factor of its cost, dependent on the price of a medicinal preparation, so we have analyzed the prices of medicinal preparations under the trade names, registered for INNs, and referred to in the standard of care for pneumonia patients.

It has been established that the minimum differences in price are characteristic of Ampicillin preparations (5.2 rubles), the maximum ones are for Ambroxol (1061.2 rubles), Levofloxacin (1452.2 rubles) and Moxifloxacin (3158.6). The obtained data correspond to the global practice and are the reasons for the emergence of stepwise antibiotic therapy, in which the ways of drug administration are combined. This increases efficiency and reduces the cost of treatment.

Based on these factors, the cost of oral and parenteral antibiotic therapy using the equivalent course dose was compared. It was revealed that the average cost of oral therapy with antibacterial drugs is 917.5 rubles, the cost of parenteral therapy is 5127.7 rubles. The minimum cost of antibiotic therapy is 219.9 rubles (the oral course of Ciprofloxacin), the maximum cost is 13913.4 rubles (parenteral course of Moxifloxacin).

Thus, the cost of a drug therapy course for CAP 
varies significantly depending on the drug's dosage form and the way of its administration.

Based on the generalization of the research results and from the standpoint of the resource approach, a conceptual model for optimizing the drug supply of CAP patients in the KBR has been developed (Fig. 4). The model consists of two parts:
- results of the assessment of the external factors (resources) of drug supply for CAP patients in Kabardino-Balkaria;

- results of the study of the internal factors of CAP pharmacotherapy (physician, patient, pharmaceutical worker; drug supply - the range and price).

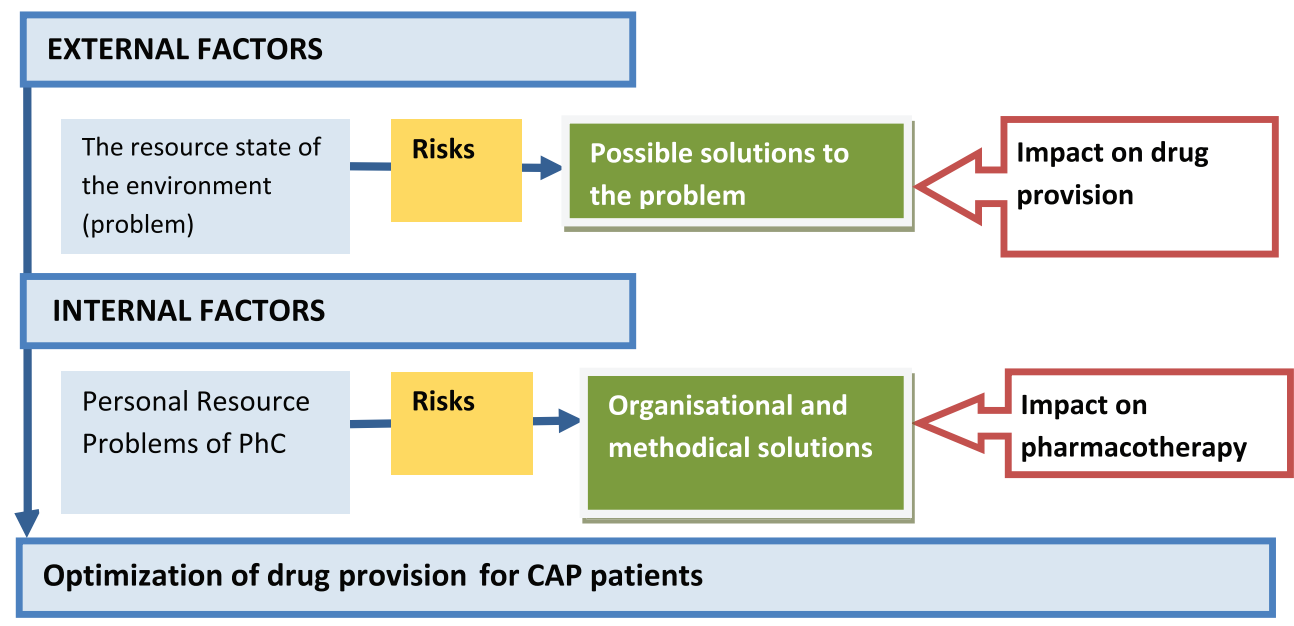

\section{Figure 4 - Scheme of conceptual model optimization of drug provision for patients with community-acquired pneumonia in the region}

The results of the factors' assessment are considered as problems causing a set of risks for drug provision and pharmacotherapy of CAP. Scientifically grounded organizational and methodological solutions aimed at reducing or eliminating manageable risks (mainly caused by internal factors) have been offered in the study.

The external factors that affect the provision of CAP treatment drugs comprise socio-demographic, organizational, personnel, financial (population) and drug resources. The main problem of these resources within the territory of the KBR is their deficit.

In particular, with regard to the organizational pharmaceutical resource, the notable problems identified in the course of the research, were the lack of accounting of pharmacy organizations and the concentration of pharmacy activities in urban areas.

The risks are:

- the difficulty of monitoring and assessing the availability of pharmaceutical organizations to the population of the KBR;

- reducing the availability of PhC for rural residents. The possible solutionis are: renewal of the previously existing system of official statistics of pharmaceutical organizations and adjustment of their location.

The main problem of the pharmaceutical human resources in the KBR is the lack of official records of pharmaceutical personnel, which leads to such risks as:

1) hiring non-core personnel to work;

2) decline in the quality of pharmaceutical services provided to the population. A possible solution, as in the previous case, is to resume the pre-existing statistics of pharmaceutists and pharmacists.

Insufficiency of the medicinal resource is in the fact that the needs of the region for CAP treatment are only satisfied by $78 \%$. This leads to the risk of reducing the physical accessibility of drugs to the public and medical organizations. A possible solution to the problem is a scientifically based and adequate determination of the region's need for drugs to carry out CAP pharmacotherapy, which, in turn, will require further training of pharmaceutical specialists in this field.

The problem of insufficient financial resources of the Kabardino-Balkarian population is confirmed by the fact that the average per capita income is lower than in the Russian Federation. Accordingly, there is a risk of reducing the economic availability of drugs for CAP patients. The prospect of a successful solution to this problem is uncertain and poorly manageable.

The problems of the socio-demographic resource of the KBR are associated with the following trends: 1) a higher rate of population aging than in the Russian Federation; 2) lower, than in the Russian Federation, share of the average annual number of employees in the total population (impact on per capita incomes); 3) outpacing, in comparison with the Russian Federation, increase in the overall incidence and CAP incidence.

These problems cause the risk of increasing the need for preferential and free drugs, as well as geriatric medical and pharmaceutical care. The possible solutions are: a systematic maintenance of regional registers of 
persons in need of guaranteed social support of the state, and uninterrupted supplys of the required drugs.

Thus, the proposed model shows that the influence of the external factors (resources of the region) leads to the risks associated with a decrease in the physical and economic accessibility of drugs to the population of the KBR as a whole and CAP patients - in particular, against the background of a decrease in the financial security of the citizens living in the region.

The second group of factors involved in the conceptual model is internal, based on the personal, behavioral characteristics of the participants in the pharmacotherapy process and, accordingly, $\mathrm{PhC}$ - the team of a physician, a patient and a pharmaceutical worker. In addition to this group of factors, the "behavior" of the drug company is attributed as one of the objects of the pharmaceutical market in the region, in particular, the variability of the cost of the drug itself and its course dose.

The main problem for this group of factors is subjectivity of behavior:

- doctor prescribing a drug for CAP pharmacotherapy, taking into account his qualification, experience, standards of treatment in force, etc.;

- patient who does not have sufficient knowledge to properly take the drug in case of pneumonia and even often cannot make the right choice in favor of going to the doctor, not to a pharmacy; - pharmaceutist, more interested in the rapid implementation of the drug, than in the preliminary direction of the patient to hospital for a detailed assessment of the patient's condition.

The risks arising from the problem of the subjectivity of the behavior of participants in PhC may, of course, be very high and serious, in terms of aggravating the disease, complications and the development of side effects.

Thus, assessing the risks of internal factors included in the model, it can be argued that all of them (a doctor, a patient and a pharmacist) are closely related to the level of their knowledge about CAP and its pharmacotherapy.

\section{REFERENCES}

1. Karapetyan TA. Vnebol'nichnaya pnevmoniya segodnya [Community-Acquired pneumonia today]. Bulletin of St. Petersburg University. Series 11: Medicine. 2008;1:1-14. Russian

2. Sinopal'nikov Al, Strachunskij NS. Novye rekomendacii po vedeniyu vzroslyh pacientov s vnebol'nichnymi pnevmoniyami [New guidelines for the management of adult patients with community-acquired pneumonia]. Clinical Microbiology and antimicrobial therapy. 2000; 3(1):54-58. Russian

3. Kabardino-Balkaria in numbers. 2018. Summary of statistics. OP North Caucasus stat on CBD-N. - Nalchik, 2018. - 183 p. Russian

4. Regions of Russia. Socio-economic indicators. 2018: Stat. SB. Rosstat. 2018: 1162 p. Russian
Therefore, the most important solution to the subjectivity problem is to increase the level of knowledge of each participant of $\mathrm{PhC}$, as well as timely and complete informe all participants in the pharmacotherapy process about CAP and its pharmacotherapy.

Such organizational and methodological solutions as the study of medical preferences, consumer demands and the opinion of pharmacy specialists regarding drugs used for CAP, have been referred to the elements of such kind of information.

Taking into account a high need of all participants of PhC for information about the CAP disease, its pharmacotherapy and related risks, specific drugs for CAP treatment and their costs in the Kabardino-Balkarian market, a methodological guide has been developed to provide information and consulting services to doctors and patients with CAP in the framework of PhC.

\section{CONCLUSION}

Thus, the state and trends of the development of organizational, personnel, socio-demographic, financial (in relation to the population) and drug resource as external factors of the drug supply system of the KBR region have been identified. It has also been established that they are insufficient to fully provide CAP patients with the required drugs.

The main problems of pharmacotherapy of CAP patients, associated with insufficient drug and informational support of doctors and patients, as well as weak interaction between medical and pharmaceutical workers, low awareness of patients about the risks of uncontrolled antibacterial drugs have been determined. In this connection, more intensive development of PhC is needed in the region.

As a result of the comprehensive research, the working hypothesis put forward previously, has been confirmed. Its use makes it possible to form a dynamic conceptual model of improving drug supply and pharmacotherapy of patients with CAP at the regional level by monitoring external and internal factors and determining the factors that are amenable to directional managerial influences.

5. Russian statistical yearbook. 2018: Stat.SB. Rosstat. - M., 2018:694. Russian

6. Health in Russia. 2017: Stat.SB. Rosstat. - M., 2017:170. Russian

7. Health in Russia. 2009: Stat.SB. Rosstat. - M., 2009:365. Russian

8. Ponomareva AA, Mozgovaya NA, Zhukova OV. Ocenka effektivnosti antibakterial'noj terapii vnebol'nichnoj pnevmonii u detej na osnove farmakoekonomicheskogo analiza [Assessment of efficiency of antibacterial therapy of community-acquired pneumonia in children on the basis of pharmacoeconomic analysis]. Medical. almanac. 2011. Special issue, March 2011: 204-205. Russian

9. Yakovlev SV. Vnebol'nichnaya pnevmoniya u pozhilyh. Osobennosti etiologii, klinicheskogo techeni- 
ya i antibakterial'noj terapii [Community-Acquired pneumonia in the elderly. Features of etiology, clinical course and antibacterial therapy]. Russian medical journal. 1999;7(16):763-768. Russian

10. Barlett JG, Breiman RF, Mandell LA, File TM. Community-Acquired Pneumonia in Adults: Guidelines for Management. Clinical Infectious Diseases. 1998; 28: 811-838.

11. Niederman MS, Mandell LA, Anzueto A. Guidelines for management of adults with community-acquired pneumonia. Diagnosis, assessment of severity antimicrobial therapy, and prevention. The official statement of the American Thoracic Society was approved by the ATC board of directors. Am. J. Respir. Crit. Care Med. 2001;163:1730-1754. DOI: 10.1164/ ajrccm.163.7.at1010

12. Yabachinskaya EN. Vozbuditeli vnebol'nichnyh pnevmonij na poroge novogo tysyacheletiya [Pathogens of community-acquired pneumonia at the threshold of the new Millennium]. Antibiotics and chemotherapy. 2000; 45(11):21-28. Russian

13. Dvoreckij LI, Yakovlev SV. Oshibki antibakterial'noj terapii infekcij dyhatel'nyh putej $v$ ambulatornoj praktike [Errors of antibacterial therapy of respiratory tract infections in outpatient practice]. The Attending physician. 2003;8:48-54. Russian

14. Hristolyubova EI, Volkova LI. Oshibki v diagnostike vnebol'nichnyh pnevmonij na dogospital'nom etape [Errors in the diagnosis of community-acquired pneumonia at the prehospital stage]. Therapeutic archive. 2005;3:33-36. Russian

15. Hristolyubova El, Volkova LI. Oshibki diagnostiki i lecheniya pnevmonij $v$ poliklinicheskih usloviyah [Errors in diagnosis and treatment of pneumonia in polyclinic conditions]. Therapeutic archive. 2005;1:8-12. Russian

16. Panfilova GL. Farmacevtichna dopomoga yak istorichna, normativno-pravova ta social'no-ekonomichna kategoriya v sistemi ohoroni zdorov'ya i farmacevtichnomu zabezpechenni naselennya [Pharmaceutical assistance as a historical, legal and socio-economic category in the system of health protection and pharmaceutical provision of the population]. Topical issues of pharmaceutical and medical science and practice. 2014;2 (15): 89-97. Russian

17. Apikoglu-Rabus S, Yesilyaprak G, IzzettinF.V Drug-related problems and pharmacist interventions in a cohort of patients with asthma and chronic obstructive pulmonary disease. Respir. Med. 2016; 120:109-115. DOI:10.1016/j.rmed.2016.10.006

18. Helper CD. The future of pharmacy pharmaceutical care. Am. J. Hosp. Pharm. 1990;30:23-29.

19. Kassam R, Collins JB, Berkowitz J. Patient satisfaction with pharmaceutical care delivery in community pharmacies.Patient Preference and Adherence. 2012;6:337-348. DOI: 10.2147/PPA.S29606.

20. Presley B, Setiabudi I, Lestiono L, Ediyono E. The Influence of Pharmaceutical Care Intervention on Inpatient Community Acquired Pneumonia: a Small Randomized Single Blind Study. J. Sains Farmasi \& Klinis. 2015;2(1):84-90. DOI: https://doi. org/10.29208/jsfk.2015.2.1.54

21. KonT, MoriM, HashimotoT. Pharmaceutical Care Approach to Treating Pneumonia among the Elderly with Intravenous Azithromycin.Iryo Yakugaku (Jap. J. of Pharm. Health Care a. Sci.). 2016; 42(9):634-644. DOI.org/10.5649/jjphcs.42.634

22. Wang YH, Fang J, Zhu BD. Pharmaceutical care of a patient with severe pneumonia complicated with Parkinson's disease. Pharm. Care a. Research. 2013; 13(2);136-139. DOI: 10.5428 / pcar20130219

23. Dremova NB, Alekseev IV. Analiz medicinskoj i farmacevticheskoj informirovannosti $\mathrm{VICH}$-inficirovannyh pacientov [Analysis of medical and pharmaceutical knowledge of HIV-infected patients]. Scientific. statements BSU. Ser. "Medicine. Pharmacy» .2012; 17(4): P. 39-44. Russian

24. Dremova NB, Ovod Al, Korzhavyh EA, Litvinova TM. Farmacevticheskaya pomoshch': termin i ponyatie [Pharmaceutical assistance: term and concept]. Pharmacy. 2005; 2: 37-45. Russian

25. Korzhavykh EA, Moshkova LV, SHukil' LV. Metodologicheskie aspekty rossijskih issledovanij po farmacevticheskoj pomoshchi [Methodological aspects of Russian researches on pharmaceutical care]. Pharmacy. 2016;1:39-42. DOI: https://doi.org/NoneRussian

26. Dremova NB, Ovod Al, Korzhavyh EA, Litvinova TM. Farmacevticheskaya pomoshch' - novoe napravlenie professional'noj deyatel'nosti provizora [Pharmaceutical assistance - a new direction of professional activity of pharmacist]. New pharmacy. 2005;10: 20-28. Russian

27. Mymrina AL, Geller LN, Tueva IA. Klasternyj podhod kak osnova processa okazaniya farmacevticheskoj pomoshchi na etape reanimacii i intensivnoj terapii [Cluster approach as the basis of the process of pharmaceutical care at the stage of resuscitation and intensive care]. Pharmacy. 2012;7: 24-26. Russian

28. Petrov AG, Knysh OI, Petrov GP. Farmakoekonomicheskaya ocenka farmakoterapii pri lechenii professional'nogo obstruktivnogo bronhita shahterov na stacionarnom urovne [Pharmacoeconomical evaluation of pharmacotherapy in the treatment of occupational obstructive bronchitis of miners at the stationary level]. Health and education in the XXI century.2017;19(2):113-116. Russian

29. Kabakova TI, Umirova AA, Korzhavyh EA. Vyyavlenie i analiz vektorov razvitiya sovremennyh issledovanij po farmacevticheskoj pomoshchi [Identification and analysis of vectors of development of modern research on pharmaceutical care]. Eurasian Scientific Association (ENO). 2019;4 (50):177-183. Russian

30. Spichak IV, Varenykh GV. Sovershenstvovanie farmacevticheskoj pomoshchi detyam s narusheniyami CNS v usloviyah stacionara na primere Belgorodskoj oblasti [Improvement of pharmaceutical care for children with CNS disorders in a hospital on the example of Belgorod region]. Scientific statement BSU. Ser. Medicine. Pharmacy. 2013;153(22):71-78. Russian

31. Spichak IV, Derekglazova YUS. Sovershenstvovanie farmacevticheskoj pomoshchi detyam s zabolevaniyami sustavov na territorii Belgorodskoj oblasti [Improvement of pharmaceutical care of children with diseases of the joints on the territory of Belgorod region]. Scientific statement BSU. Ser. Medicine. Pharmacy. 2013.;154(22):39-46. Russian

32. Trubina LV, Pen'evskaya NA. Sovershenstvovanie farmacevticheskoj pomoshchi klientam aptek po voprosam profilaktiki infekcij, perenosimyh iksod- 
ovymi kleshchami [Improvement of pharmaceutical care to clients of pharmacies in the prevention of infections transmitted by lxodes ticks]. Fundamental research. 2014; 11:1333-1339. Russian

33. Yachnikova MA. Sovremennye podhody k organizacii farmacevticheskogo konsul'tirovaniya klienta aptek, priobretayushchego antiseptiki dlya lecheniya boli $v$ gorle [Modern approaches to the organization of pharmaceutical counseling of client pharmacies acquiring antiseptics for the treatment of pain in the throat]. Omsk scientific. bulletin. Sir. «Earth resources. Man.». 2012; 2 (114): 89-91. Russian

34. Zakaryaeva ZT, Andreeva IN. Osobennosti lekarstvennogo obespecheniya bol'nyh pnevmoniyami na etape stacionarnogo lecheniya v RSO-Alaniya [Peculiarities of provision of medicines of patients with pneumonia at the stage of inpatient treatment in RSO-Alania]. Modern problems of science and education. 2013; 3. URL: https://science-education.ru/ ru/article/view?id=9549Russian

35. Zemskova NA, Loskutova EE. Nekotorye farmakoekonomicheskie aspekty netyazheloj vnebol'nichnoj pnevmonii. Assortiment antibakterial'nyh preparatov $v$ aptekah [Some pharmacoeconomical aspects of mild community-acquired pneumonia. The range of antibacterial drugs in pharmacies]. Bulletin of the Russian University of friendship of peoples. 2007:62-64. Russian

36. Bell JS, Väänänen $M$, Ovaskainen H. Providing Patient Care in Community Pharmacies: Practice and Research in Finland. Ann. Pharmacother. 2007; 41 (6):1039-1046. DOI.org/10.1345/aph.1H638

37. Besançon L. Pharmaceutical Care. Summary of a survey from the Council of Europe. FIP.2010:32.
38. Perraudin C, Brion F, Bourdon O, Pelletier-Fleury N. The future of pharmaceutical care in France: a survey of final-year pharmacy students' opinions. BMC Clin. Pharmacol. 2011; 11:6 doi: 10.1186 / 14726904-11-6 DOI: 10.1186 / 1472-6904-11-6.

39. Curtiss FR. Clinical Pharmacist Interventions Associated with Appropriateness and Lengthof Inpatient Antimicrobial Therapy for Pneumonia. J. Manag. Care Spec. Pharm. 2002; 8(5):406-406. DOI: 10.18553 / jmcp.2002.8.5.406

40. Dzhuparova IA. Tipologiya farmacevticheskoj pomoshchi l'gotnym kategoriyam grazhdan v Sibirskom federal'nom okruge [Typology of pharmaceutical care preferential categories of citizens in the Siberian Federal Region]. Medicine and education in Siberia. 2010;5:10-18. Russian

41. Dzhuparova IA, Sboeva SG. Tipologiya farmacevticheskoj pomoshchi otdel'nym kategoriyam grazhdan v Sibirskom federal'nom okruge [Typology of pharmaceutical care to separate categories of citizens in the Siberian Federal district]. Bulletien of the Voronezh state University. Ser.: Chemistry. Biology. Pharmacy. 2010;2:140-143. Russian

42. Shukil' LV. Opyt okazaniya specializirovannoj farmakologicheskoj pomoshchi bol'nym saharnym diabetom v Omskoj oblasti [Experience in providing specialized pharmaceutical care for patients with diabetes in the Omsk region]. Sib. Med. journal. (Irkutsk.) 2013; 118(3): 94-96 Russian

43. Fomina AV, Moshkova LV. Dostupnost' lekarstvennoj pomoshchi naseleniyu: faktory vliyaniya [Availability of medical care to the population: factors of influence]. New pharmacy. The Director of pharmacy. 2004;3: 48-52. Russian

FINANCIAL SUPPORT

This study did not have any financial support from outside organizations.

\section{AUTHORS' CONTRIBUTION}

All authors equally contributed to the research work.

\section{CONFLICT OF INTEREST}

The authors declare no conflict of interest.

\section{AUTHORS}

Adisa A. Umirova - postgraduate student, Department of Economics and Organization of Healthcare and Pharmacy, Pyatigorsk Medical and Pharmaceutical Institute, branch of Volgograd State Medical University, Ministry of Health of the Russian Federation, branch of the Federal State Budgetary Institution of Higher Education. ORCID: 0000-0002-8371-7570. E-mail: adisaumirova@gmail.com

Vsevolod L. Adzhienko - Doctor of Sciences (Medicine), Professor, Head of the Department of Economics and Organization of Healthcare and Pharmacy of Pyatigorsk Medical and Pharmaceutical Institute - a branch of Federal State Budgetary Institution of Higher Education "Volgograd State Medical University" of the Ministry of Health of the Russian Federation. ORCID: 0000-0002-5269-4150.E-mail: adzhienko@yandex.ru

Taisiya I. Kabakova - Doctor of Sciences (Pharmacy), Associate Professor, Professor at the Department of Organization and Economics of Pharmacy of Pyatigorsk
Medical and Pharmaceutical Institute - a branch of Federal State Budgetary Institution of Higher Education "Volgograd State Medical University" of the Ministry of Health of the Russian Federation. ORCID: 0000-00016182-5637. E-mail: kabtais@mail.ru

Eleonora A. Korzhavykh - Doctor of Sciences (Pharmacy), Federal State Autonomous Educational Institution of Higher Education "Peoples' Friendship University of Russia". ORCID: 0000-0002-4958-9018. E-mail: o_kea@mail.ru

Vladimir V. Gatsan - Doctor of Sciences (Pharmacy), Professor, Head of the Department of Organization and Economics of Pharmacy of Pyatigorsk Medical and Pharmaceutical Institute - a branch of Volgograd State Medical University, a branch of the Federal State Budgetary Institution of Higher Education of the Ministry of Health of the Russian Federation. ORCID: 0000-00031815-7869. E-mail: GacanVV@yandex.ru 